\title{
AL-QURAN DAN PEMANFAATAN PERMAINAN EDUKATIF PADA ANAK USIA DINI
}

\author{
Oleh : Atik Wartini \& Muhammad Askar \\ Mahasiswa Pasca Sarjana PGRA \\ UIN Sunan Kalijaga Yoyakarta \\ Email: Hadiari701@yahoo.com
}

\begin{abstract}
This research is based on a literature review, in this study the theme was related to the Koran and utilization of educational games for children early age, in this paper, there are three first questions how the Koran speaks of utilization Educational games, both what just utilization educational games, and any third party utilization educational games, with the method of content analysis it will be produced first know the Koran speaks utilization of educational games, second, meaning educational games, and third to know what can be utilized in educational games.
\end{abstract}

Keywords : Permainan Edukatif, Al-Quran, Pemanfaatan

\section{A. Pendahuluan}

Dunia anak-anak adalah kehidupan yang penuh dengan bermain. Permainan dan anak-anak merupakan dua hal yang berbeda tetapi satu dengan yang lainnya tidak dapat dipisahkan. Dapat dikatakan bahwa hampir sepanjang masa kanak-kanak tidak terlepas dari permainan. Untuk membahas lebih lanjut, sekiranya perlu memahami beberapa hal dengan jelas terlebih dahulu, yaitu sebagai berikut. (1) bermain menurut Semiawan, merupakan aktivitas yang dipilih sendiri oleh anak, karena menyenangkan bukan karena akan memperoleh hadiah dan 
pujian ${ }^{1}$. Dalam hal ini yang perlu lebih diperhatikan maknanya dalam bermain yaitu aktivitas yang dilakukan untuk memperoleh kesenangan. Kondisi untuk memperoleh kesenangan seperti ini dapat dijumpai dalam hadis Rasul, antara lain sebagai berikut:
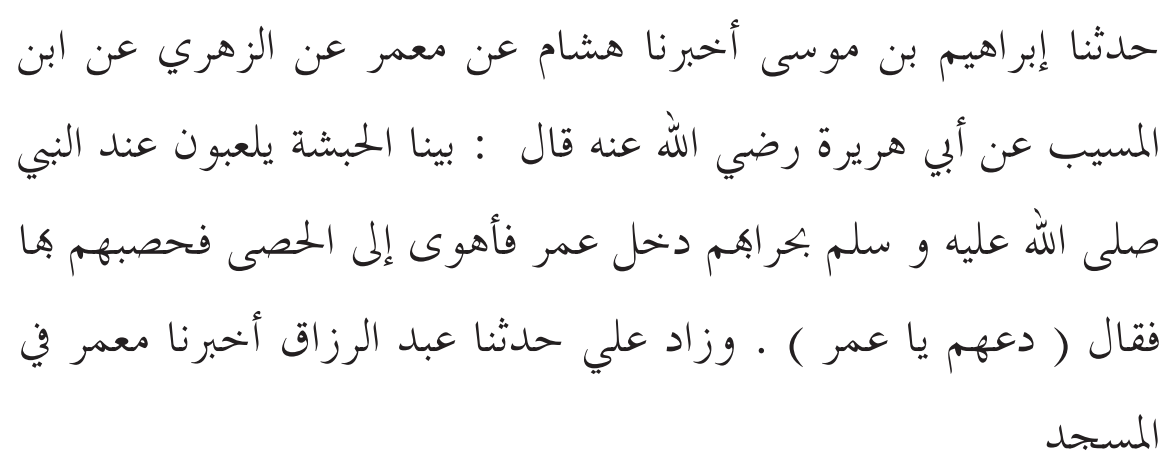

Artinya : Dari Abu Hurairah r.a ujarnya: ketika orang-orang Habsyi bermain tombak di hadapanRasulullah saw, tiba-tiba datang Umar Bin Khatabb r.a lalu ia mengambil batu-batu kecil dan mereka dilontari dengan batu-batu tersebut. Rasulullah SAW bersabda: "Biarkanlah mereka bermain hai Umar", dan Ali menambahkan bahwa telah menceritakan kepada kami Abdur Razak yang juga telah menceritakan kepada kami makmar tentang hal itu yang terjadi di Masjid. (HR. Bukhari). ${ }^{2}$

Dengan demikian bermainpun diperkenankan dalam ajaran Islam, karena diperlukan dalam kehidupan manusia untuk memperoleh kesenangan. Kegiatan bermain tidak terikat pada waktu tertentu kapan saja dikehendaki dapat dilakukan. Akan

1 Sofia Hartati, Perkembangan Belajar pada Anak Usia Dini,(Jakarta : Direktorat Pendidikan Nasional Direktorat Jenderal Pendidikan Tinggi Direktorat Pembinaan Pendidikan Tenaga Kependidikan dan Ketenagaan Perguruan Tinggi Jakarta, 2005), hlm. 85.

2 Bukhari, Al Jami' Al Shokih Al Bukhari, (Bairut: Dar Al Kutub Al Ilmiyah, 2000), Jilid 3 Hlm. 1063. 
tetapi Islam juga memberikan petunjuk agar umat Islam tidak melalaikan diri taat kepada Allah atau menyia-nyiakan waktu akibat asyik bermain hanya untuk memperoleh kesenangan semata. Keadaạ ini seperti dalam Al-quran sebagai berikut :

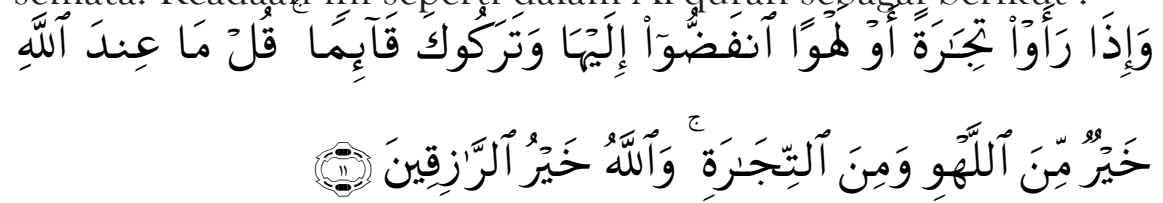

Artinya : Dan apabila mereka melihat perniagaan atau permainan, mereka bubar untuk menuju kepadanya dan mereka tinggalkan kamu sedang berdiri (berkhotbah). Katakanlah: "Apa yang di sisi Allah lebih baik daripada permainan dan perniagaan", dan Allah Sebaik-baik pemberi rezki. (Al jumah : 11).

Memperoleh kesenangan diperkenankan, tetapi melalaikan diri dari taat kepada Allah akibat terpengaruh memperoleh kesenangan sangat dicela dalam ajaran Islam. Oleh karena itu perlu dipahami tujuan dari bermain yaitu bermain itu sendiri, ${ }^{3}$ dan dalam kaitannya dengan anak-anak perlu memperhatikan esensi waktu, sehingga anak-anak akan belajar role dalam bermain sejak dini. Selanjutnya, (2) Permainan adalah sesuatu yang dijadikan untuk bermain. ${ }^{4}$ Dalam hal ini dapat dimaknai bahwa dalam permainan ada kegiatan bermain baik menggunakan alat atau tanpa alat.

3 Rahmat, "Memanfaatkan Permainan Bagi Pendidikan Emosional", dalam Jurnal : Ilmu Pendidikan Islam : Kajian tentang Konsep, problem dan prospek pendidikan Islam, (Yogyakarta : Fakkultas Tarbiyah UIN Sunan Kalijaga Yogyakarta, 2003), hlm. 211.

${ }^{4}$ Indah Nuraini, Kamus Bahasa Indonesia, (Bogor : CV. Duta Grafika, 2010), hlm. 612. 
Sudah tidak tabu lagi bahwa dalam permainan banyak aspek-aspek perkembangan anak yang dapat dikembangkan. Permainan akan mampu mengembangkan aspek dengan baik bila terdapat educator / orang tua yang kreatif sehingga mampu memanfaatkan permainan edukatif terlebih melalui banyak hal yang telah disediakan oleh alam lingkungan sekitar. Permainan edukatif mempunyai arti yang lebih luas, dalam hal ini dapat merangsang aspek perkembangan anak dan mempunyai nilai edukatif, serta memperhatikan tingkat keamanan yang memadai dengan nilai estetik yang baik. Menurut pemakalah pada dasarnya permainan terbagi menjadi dua, yaitu permainan edukatif dan permainan non edukatif atau permaian edukatif yang didesain dan permainan edukatif yang langsung bisa dipakai. Berkaitan dengan ini juga terdapat permainan tradisional dan modern.

Dewasa ini berkenaan dengan permainan edukatif, terdapat sejumlah media/alatyangdapatmembantuagaraktivitas bermaian lebih bermakna dan mampu menstimulasi perkembangan anak dengan maksimal. Hal ini berarti media / alat permainan tidak akan dapat berfungsi apa-apa jika tidak ada user / pembimbing yang menggunakannya atau memfungsikannya. Oleh karena itu inilah pentingnya educator / orang tua perlu memanfaatkan permainan edukatif dengan sekreatif dan semaksimal mungkin.

Dewasa ini masih terdapat educator / orangtua yang tidak mudah untuk berkreativitas, dengan alasan kreatif itu sulit, susah dan tidak adanya waktu yang cukup atau inginnya serba instan. Kreativitas merupakan suatu proses mental seseorang yang melahirkan gagasan, proses, metode ataupun produk baru yang efektif yang bersifat imajinatif, estetis, fleksibel, integrasi, 


\section{Al-Qurian dan Pemanfatan Permainan Edukatif ...}

Atik Wartini \& Mulammad Askar

diferensiasi yang berdayaguna dalam berbagai bidang untuk memecahkan masalah. ${ }^{5}$ Dari pengertian ini terdapat suatu strategi untuk membantu agar seorang dapat belajar menjadi kreatif, misalnya seperti senang membaca buku / pemikiran tokoh / orang lain, observasi di lapangan, berdiskusi, dan senang berimajinasi, sehingga seseorang mampu mengkontruksi pikirannya dengan pengalaman yang telah dilihatnya sehingga mampu menginovasikan menjadi hal yang lebih baru dan menarik.

Dewasa ini ketika educator / orangtua mampu berkreativitas, maka akan mampu memanfaatkan permainan edukatif terlebih untuk permainan yang non edukatif sehingga menjadi pemainan yang mempunyai nilai edukatif. Perlu dikaji lebih lanjut, bahwa lingkungan alam telah banyak menyediakan pembelajaran agar mampu dikelola dengan maksimal. Oleh karena itu sekiranya perlu menelaah lagi tentang satu dari banyaknya ayat Allah SWT yang menjelaskan tentang pemanfaatan lingkungan. Karena jika dilihat dari perspektif pendidikan, lingkungan mempunyai banyak kemanfaatan untuk di jaga dan dilestarikan sebagai sumber belajar, media pembelajaran dan sumber penghidupan bagi makhluk bumi baik yang terpelajar ataupun tidak. Sehingga nyata adanya jika Allah SWT menciptakan segala hal pasti ada manfaatnya.

\footnotetext{
5 Yeni Rachmawati \& Euis Kurniati, Strategi Pengembangan Kreativitas Pada Anak Taman Kanak-kanak, (Jakarta : Departemen Pendidikan Nasional Direktorat Jenderal Pendidikan Tinggi Rektorat Pembinaan Pendidikan Tenaga Kependidikan dan Ketenagaan Perguruan Tinggi Jakarta : 2005), hlm. 15.
} 


\section{4 \\ JURNAL AL-AFKAR \\ Vol. III, No. 1, April 2015}

\section{B. Pembahasan}

\section{a. Telaah Ayat Al-Quran tentang Pemanfaatan Permainan Edukatif}

Pada upaya menelaah ayat Al quran ini, pemakalah akan memaparkan sedikit tafsir dari banyaknya tafsir yang sudah ada, agar pembelajaran dapat dipahami secara integrasi dan interconnection, bahwa teori yang ada adalah secuil dari ayat Alquran, yaitu surat Al Baqarah ayat : 22 .

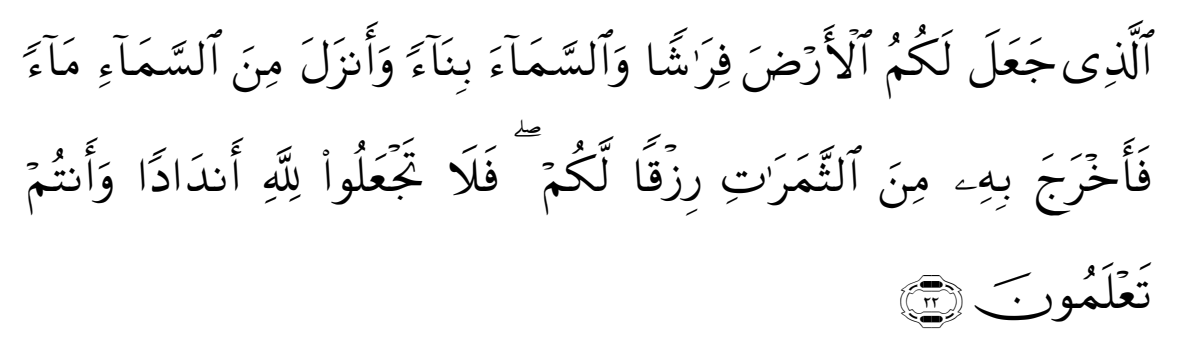

Artinya: Dialah yang menjadikan bumi sebagai hamparan bagimu dan langit sebagai atap, dan Dia menurunkan air (hujan) dari langit, lalu Dia menghasilkan dengan hujan itu segala buah-buahan sebagai rezki untukmu; karena itu janganlah kamu Mengadakan sekutu-sekutu bagi Allah, Padahal kamu mengetahui.

Sekelumit tafsir surat Al baqarah ayat 22 yaitu, Allah bukan hanya menciptakan kamu, tetapi Dia juga yang menjadikan bumi hamparan untuk kamu. Kalau kata khalaqa / mencipta memberi kesan wujudnya sesuatu, baik melalui bahan yang telah ada sebelumnya maupun belum ada, serta menekankan bahwa wujud tersebut sangat hebat dan tentu lebih hebat lagi Allah yang mewujudkannya. Kalau kata khalaqa demikian halnya maka kata ja'ala, mengandung makna mewujudkan sesuatu dari bahan yang 
telah ada sebelumnya sambil menekankan bahwa yang wujud itu sangat bermanfaat dan harus diraih manfaatnya, khususnya oleh yang untuknya dijadikan bumi ini terhampar harus meraih manfaat lahir dan batin, material dan spiritual dari dijadikannya bumi ini terhampar. Jangan biarkan bumi, tanpa dikelola dengan baik, makmurkan ia untuk kemaslahatan hidup, sambil mengingat bahwa sebagaimana ada makhluk yang diciptakannya sebelum kamu, ada juga makhluk yang akan datang sesudah kamu. Yang sebelum kamu telah memanfaatkan bumi ini tanpa menghabiskannya, bahkan masih menyisakan banyak untuk kamu, maka demikian juga seharusnya kamu wahai seluruh manusia masa kini, jangan habiskan atau rusak bumi. Ingatlah generasi sesudah kamu. ${ }^{6}$

Lebih spesifikasi jika dilihat dari sudut pandang makalah ini, bahwa sejatinya Allah telah memberikan rizki yang tidak hanya sebatas buah-buahan yang tumbuh akibat hujan, tetapi lebih luas yaitu segala hal yang terhampar di bumi ini. Terutama yang lebih dekat dengan kehidupan manusia yaitu lingkungan alam sekitar. Manusia ditekankan untuk memanfaatkan segala yang ada di alam sekitar, baik manfaat lahir, batin, spiritual dan material. Bahkan dikelola agar bermaslahat untuk kehidupan.

Dewasa ini jika ditelaah lebih lanjut hal ini merupakan sebagai sumber belajar berupa permainan yang notabene telah disediakan oleh alam / tinggal memakainya saja dan bisa diinovasikan dengan desain yang akan mempunyai nilai lebih seperti nilai-nilai edukatif, estetika, dan mampu mengbangakan aspek perkembangan anak. Oleh karena itu, sudah seharusnya,

${ }^{6}$ M. Qurais Shihab, Tafsir Al Misbah, Pesan Kesan dan Keserasian Al-Quran, (Jakarta : Lentera Hati, 2002), hlm. 122-125. 


\section{6 \\ JURNAL AL-AFKAR \\ Vol. III, No. 1, April 2015}

setiap educator / orangtua agar berusaha untuk memanfaatkan lingkungan untuk dijadikan sumber belajar ataupun media dan alat permainan yang edukatif dengan menginovasi yang sudah diciptakan Tuhan. Misalnya, dedaunan yang ada disekitar lingkungan dapat digunakan untuk keterampilan sains, matematika dengan menghitung jumlahnya, art dijadikan alat / media untuk menggambar baik berupa mix media picture, kolase, pengecap dll. Tentunya alam akan memberikan warna tersendiri jika educator / orangtua mampu memanfaatkannya sesuai dengan kebutuhan dan kreativitas masing-masing. Oleh karena itu, sesungguhnya Al Qur'an telah mengenalkan prinsip-prinsip permainan yang edukatif, karena Al Quran adalah hudalinnas / peunjuk bagi manusia dan Al Quran mempunyai nilai universalitas. Hal ini dibuktikan dengan adanya teori tentang permainan edukatif dan kreativitas yang ditelaah secara akademis.

\section{b. Pengertian Pemanfaatan}

Dalam kamus bahasa Indonesia manfaat merupakan kata benda yang artinya faedah, guna, laba, untung. Sedangkan bermanfaat merupakan kata kerja yang artinya ada manfaatnya, berhasil guna. Memanfaatkan merupakan kata kerja yang artinya menggunakan, menjadikan manfaat. Pemanfaatan merupakan kata benda yang artinya menggunakan, menjadikan manfaat. ${ }^{7}$ Dari beberapa paparan kata manfaat dan imbuhannya, dalam hal ini jika dikaitkan dengan permainan edukatif, bahwa pemanfaatan permainan edukatif adalah suatu upaya menggunakan permainan edukatif atau menjadikannya lebih bermanfaat. Senada dengan

\footnotetext{
7 Indah Nuraini, Kamus Bahasa Indonesia, hlm. 620.
} 
hal ini, menurut penulis permainan edukatif di bagi menjadi dua yaitu, permainan edukatif dan permainan non edukatif, baik yang di desain atau langsung bisa dipakai.

Dilihat dari pembagian permainan eduakatif, hal ini lebih banyak mengarah pada bagaimana desainer / educator / orangtua berupaya memanfaatkan permainan non edukatif / yang ada disekitar lingkungan dan belum dimanfaatkan atau diinovasi agar mempunyai manfaat lebih banyak dalam aspek perkembangan anak dan pendidikan. Contohnya seperti, memanfaatkan permainan tradisonal / menggunakan bahan-bahan yang ada disekitar lingkungan untuk dijadikan sebagai sumber / alat dan bahan permainan. Lebih kongkrit batu dijadikan sebagai media utuk mengenal bilangan, daun pisang digunakan untuk membuat orang-orangan, Koran bekas dijadikan sebagai media tanam dll.

Selanjutnya menurut hemat pemakalah, jika ditelaah lebih lanjut bahwa perlu adanya suatu upaya atau proses menggunakan dan menjadikan suatu hal itu bermanfaat, berarti dalam kenyataannya dan khususnya di lembaga PAUD masih terdapat pendidik yang belum semuaya mampu berkreativitas secara stabil dan menggunakan alat permainan edukatif (APE) atau permainan edukatif yang ada di lingkungan PAUD sendiri. Bahkan memanfaatkan dan menggunakan permainan yang notabene belum mempunyai nilai edukatif untuk diupayakan menjadikannya mempunyai nilai edukatif dan bisa mengembangkan aspek perkembangan anak. Khususnya dalam pembuatan APE, tentunya dengan memperhatikan syarat 


\section{8 \\ JURNAL AL-AFKAR \\ Vol. III, No. 1, April 2015}

pembuatan $\mathrm{APE}^{8}$, baik syarat edukatif, ${ }^{9}$ syarat teknis ${ }^{10}$ dan syarat estetika $^{11} \cdot{ }^{12}$

\section{c. Pengertian Bermain Edukatif}

Bermain merupakan suatu kegiatan yang sangat digemari anak. Bermain pada anak pada intinya adalah proses belajar anak itu sendiri. Dengan bermain, anak-anak dapat melakukan kegiatan yang merangsang dan mendorong pengembangan aspek-aspek kemampuan dan potensi anak. Anak belajar dimulai dari objek nyata, oleh karena itu agar lebih bermakna dan hasilnya baik, harus ditunjang dengan sarana atau alat permainan yang mengandung nilai-nilai edukatif.

Bermain ada yang dapat dilakukan tanpa menggunakan alat dan ada juga yang menggunakan alat. Tetapi pada umumnya

8 Syarat pembuatan APE : aman, ukuran dan berat sesuai usia anak, desain harus jelas, mengembangkan berbagai aspek perkembangan anak, dimainakan dengan berbagai variasi, sederhana dan menarik baik warna / bentuknya, jika ada suara harus jelas, APE harus mudah diterima oleh semua kebudayaan, tidak mudah rusak. Lebih lanjut baca Soetijiningsih (1995) dalam Nelva Rolina, Alat Permainan Edukatif PAUD, (Yogyakarta : Ombak, 2012), hlm. 14.

9 Syarat edukatif : pembuatan APE disesuaikan dengan program pendidikan dan kurikulum yang berlaku dengan tujuan mampu membantu pencapaian tujuan program pendidikan sehingga mampu mendorong kreativitas dan aktivitas anak sesuai kemampuan. Lebih lanjut baca Badru Zaman dalam Nelva Rolina, Alat Permainan Edukatif PAUD, (Yogyakarta : Ombak, 2012), hlm. 12.

${ }^{10}$ Syarat Teknis : perlu memperhatikan kualitas bahan, pemilihan warna, kekuatan bahan dalam suhu tertentu, dirancang sesuai tujuan, multiguna, menggunakan bahan yang mudah didapat, aman, awet, mudah digunakan baik secara individual / kelompok / klasikal. Lebih lanjut baca Nelva Rolina, Alat Permainan Edukatif PAUD, (Yogyakarta : Ombak, 2012), hlm.13.

${ }^{11}$ Syarat Estetika :berkaiatan dengan unsure keindahan APE yang dibuat agar memotivasi dan menarik perhatian anak untuk digunakan, seperti bentuknya yang elastic, keserasian ukuran, kombinasi warna serasi dan menarik. Lebih lanjut baca Nelva Rolina, Alat Permainan Edukatif PAUD, (Yogyakarta : Ombak, 2012), hlm. 14.

${ }^{12}$ Nelva Rolina, Alat Permainan Edukatif PAUD, (Yogyakarta : Ombak, 2012), hlm. 12-14. 


\section{Al-Qur'an dan Pemanfatan Permainan Edukatif ...}

Atik Wartini \& Mulammad Askar

kegiatan bermain lebih banyak menggunakan alat. Alat permainan yang digunakan, ada yang dibuat khusus untuk kegiatan bermain seperti boneka, mobil-mobilan dan lain-lain yang dijual di toko-toko mainan tetapi ada pula yang dibuat sendiri dengan menggunakan bahan-bahan yang ada di sekitar anak seperti mainan dari kulit jeruk, pistol-pistolan dari pelepah pisang dan lain-lain. ${ }^{13}$

Ciri-ciri bermain berdasarkan analisa fenomenologis oleh Buytendijk seperti yang dikutip Trisnawati adalah:

a. Permainan adalah aktivitas bermain dengan sesuatu.

b. Dalam permainan selalu ada sifat timbal balik, sifat interaksi.

c. Permainan berkembang, tidak statis tetapi dinamis, sebuah proses dialektik tese-antitese-sintese. Karena adanya proses yang berputar ini maka akan tercapai sebuah klimaks dan proses dapat dimulai dari awal lagi.

d. Lebih menekankan pada proses yang berlangsung dibandingkan hasil akhir.

e. Bebas memilih dan ciri ini merupakan elemen yang sangat penting bagi konsep bermain anak.

f. Mempunyai kualitas pura- pura, kegiatan bermain mempunyai kerangka tertentu yang memisahkan nya dari kehidupan nyata sehari-hari. ${ }^{14}$

Oleh karena itu dapat disimpulkan bahwa bermain edukatif adalah kegiatan / aktivitas yang disenangi anak baik

13 Badru Zaman, "Pengembangan Alat Permainan Edukatif di Lembaga Pendidikan Anak Usia Dini (PAUD)", dalam badruzaman.staf.upi.edu, diakses 6 Maret 2015.

14 Trisnawati, "Efektivitas Permainan Lego dalam Meningkatkan Kreatifitas Anak Usia Prasekolah”, dalam digilib.uinsby.ac.id, diakses 6 Maret 2015. 


\section{0 \\ JURNAL AL-AFKAR \\ Vol. III, No. 1, April 2015}

menggunakan alat ataupun tidak dan menimbulkan rasa senang serta mempunyai nilai-nilai edukatif untuk mengembangkan aspek perkembangan anak.

\section{d. Pengertian Permainan Edukatif}

Ada tiga jenis permainan yang dikenal dalam penelitian anak usia dini menurut Weikart, Rodgers, Adcock, Erik Erikson, Jean Piaget, Lev Vygotsky, dan Anna Freud dalam Yohana Rumanda dan Hikmah, yaitu sensorimotor atau permainan fungsional, permainan peran (mikro dan makro), dan permain pembangunan. Dalam permainan sensorimotor anak melakukan sesuatu berulangkali untuk menikmati sesuatu yang baru dikuasai dan menegaskan kepada dirinya sendiri kemampuan yang baru diperoleh, misalnya anak mengayak pasir atau menepuk air dengan jari jemarinya. Anak akan menikmati efek tindakan ini dan senang atas kemampuan barunya. bermain ini utamanya dilakukan oleh anak-anak usia lahir hingga dua tahun, namun tetap penting sepanjang masa kanak-kanak. Kebutuhan bermain sensorimotor dipenuhi apabila lingkungan bermain baik di dalam maupun di luar menyediakan kesempatan bagi anak untuk berinteraksi dengan berbagai tekstur, warna, bentuk, ukuran, dan jenis-jenis bahan main lainnya. ${ }^{15}$

Bermain peran merupakan pengalaman penting yang mendukung perkembangan anak secara keseluruhan; kognisi, sosial, emosi, dan bahasa. Phelps menurut Yohana Rumanda dan Hikmah, telah mengembangkan sebuah alat penilaian bermain

\footnotetext{
15 Yohana Rumanda dan Hikmah, Pembelajaran Anak Usia Dini yang Menyenangkan Melalui Bermain, (Kemendiknas, Dirjen PAUDNI, Direktorat PPTK PAUDN, 2011), hlm. 35-36.
} 
peran dan menggunakan alat inti untuk mengamati anak-anak. Ia menemukan bahwa kemampuan anak bermain peran berkaitan langsung dengan: pengungkapan kata-kata yang lebih baik, kosa kata yang lebih kaya, pemahaman bahasa lebih tinggi, strategi pemecahan masalah lebih baik, lebih ingin tahu, kemampuan melihat sudut pandang orang lain lebih baik, kemampuan intelektual lebih tinggi, bermain dengan teman lebih banyak, agresi menurun, empati lebih banyak, lebih imajinatif, rentang perhatian lebih panjang, kemampuan perhatian lebih besar, dan kinerja tugas-tugas percakapan lebih banyak. ${ }^{16}$

Bermain pembangunan merangsang anak menggunakan objek atau bahan-bahan bermain untuk menciptakan sesuatu, misalnya menggunakan deretan balok besar mewakili jalan, balok kecil mewakili mobil. Wolfgang dalam Yohana Rumanda dan Hikmah menjelaskan bahwa terdapat suatu kontinum dari bahan-bahan main pembangunan mulai dari sifat paling cair hingga ke paling terstruktur. Bila penggunaan dan bentuk dari bahan-bahan main ditentukan oleh anak, seperti cat, krayon, spidol, play dough, pasir, dan lumpur maka disebut bahan main sifat cair. Namun apabila penggunaan ditentukan oleh bahanbahan bermain tersebut, seperti balok unit, lego, balok berongga, dan puzzle maka dianggap sebagai bahan bermain pembangunan terstruktur. ${ }^{17}$

Melalui ketiga indikator tersebut, sebuah permainan akan lebih mudah diidentifikasi apakah mengandung nilai edukasi atau tidak. Pengertian senada dikemukakan oleh McCall

\footnotetext{
${ }^{16}$ Yohana Rumanda dan Hikmah, Pembelajaran Anak Usia Dini yang Menyenangkan Melalui Bermain, (Kemendiknas, Dirjen PAUDNI, Direktorat PPTK PAUDN, 2011), hlm. 36-37.

${ }^{17} \mathrm{Ibid}, \mathrm{hlm} .37$.
} 


\section{JURNAL AL-AFKAR \\ Vol. III, No. 1, April 2015}

dan Kavanaugh. McCall dan Kavanaugh menyatakan bahwa permainan agar dapat bernilai edukatif jika mengandung bentuk:

a. Eksploratif: Menggerak-gerakkan suatu benda.

b. Konstruktif: Membangun atau menyusun sesuatu.

c. Permainan pura-pura. ${ }^{18}$

Melalui menggerak-gerakkan suatu benda, maka anak telah mengaktifkan panca indera dan mengembangkan motoriknya. Melalui membangun atau menyusun sesuatu, anak telah melalui suatu proses dan berhasil untuk menyusun sesuatu yang baru yang sebelumnya belum ada. Melalui bermain pura-pura, anak terlatih untuk keluar dari egosentrisnya, anak belajar memahami diluar dirinya, dan merasakan bahwa ada orang atau sesuatu yang lain selain dari dirinya dan mulai berusaha untuk memahaminya.

Sebagai gambaran, diambil contoh bermain puzzle orang. Unsur menggerak-gerakkan suatu benda: meletakkan, mengambil kembali, meletakkan kembali, atau menggeser-geser kepingan puzzle sampai semua potongan puzzle berada tepat pada tempatnya. Indera dan motorik anak terasah pada saat kegiatan ini.

Unsur membangun atau menyusun sesuatu: proses menggerakgerakkan suatu benda berakhir ketika semua kepingan puzzle berada tepat ditempatnya. Ketika sudah tercapai pada langkah ini, anak sudah menghasilkan sesuatu yang sebelumnya belum ada. Bentuk yang semula hanya kepingan-kepingan, setelah disusun menjadi bentuk baru yaitu orang.

\footnotetext{
${ }^{18}$ Mansur, Pendidikan Anak Usia Dini dalam Islam, cet. IV (Yogyakarta: Pustaka Pelajar, 2011), hlm. 154.
} 
Unsur permainan pura-pura: puzzle orang berubah menjadi sebuah poto ayah anak atau kakek anak, andai puzzle seorang laki-laki. Atau menjadi sebuah poto ibu atau nenek ketika puzzle seorang perempuan. Kemudia secara bersama mengajak bicara (bermain pura-pura) kepada ayah/ibu atau kakek/nenek.

Permainan edukatif (PE) mempunyai arti yang lebih luas dari pada alat permainan edukatif (APE). Permainan edukatif adalah kegiatan / aktivitas bermain yang di desain atau sudah tersedia yang menstimulasi aspek perkembangan anak dan meningkatkan kreativitas. Sedangkan APE adalah berupa alat / bendanya yang mempunyai nilai edukatif untuk mengembangkan aspek perkembangan anak. ${ }^{19}$ Oleh karena itu, di dalam PE secara langsung terdapat alat dan aktivitas bermain, sedangkan pada APE hanya terdapat Alat permainannya saja. Contohnya, Petak umpet (permaina tradisional) sebagai PE sedangkan puzzle sebagai APE.

APE untuk anak usia dini dirancang dengan pemikiran yang mendalam disesuaikan dengan rentang usia anak. ${ }^{20}$ Berikut beberapa contoh permainan dukatif yang sesuai dengan rentang usia anak. Puzzle untuk anak usia 2-3 tahun dengan jumlah 1 keping yang ada pegangan untuk ditarik dan di pasang. Puzzle untuk anak usia 4-5 jumlah 6 keping, dan untuk usia 5-6 tahun lebih dari 10 keping. ${ }^{21}$

${ }^{19}$ Cucu Eliyawati, Pemilihan dan Pengembangan Sumber Belajar untuk Anak Usia Dini, (Jakarta : (Jakarta : Departemen Pendidikan Nasional Direktorat Jenderal Pendidikan Tinggi Rektorat Pembinaan Pendidikan Tenaga Kependidikan dan Ketenagaan Perguruan Tinggi Jakarta : 2005), hlm. 62).

${ }^{20}$ Ibid., hlm. 63

${ }^{21}$ Direkturat Jenderal PAUDNI, Petunjuk teknis penyelenggaraan PAUD-TPQ. (Jakarta:Direkturat Jenderal Pendidikan Anak Usia dini Nonformal dan Informal, 2011), hlm. 38-40. Lebih lanjut terlampir. 


\section{JURNAL AL-AFKAR \\ Vol. III, No. 1, April 2015}

\section{e. Urgensi Kreativitas dalam Pemanfaatan Permainan Edukatif}

Dimulai dari masa bayi potensi kreatif pada setiap anak telah terlihat dari gaya belajar natural yaitu senang mengeksplorasi apapun yang ada disekitar lingkungannya. Dengan potensi kreatif alami yang dimilikinya, maka seorang anak akan senantiasa membutuhkan aktivitas yang syarat dengan ide-ide kreatif. Oleh karena itu, anak usia dini perlu memperoleh stimulasi yang dapat mengembangkan potensi kretifnya secara maksimal, sehingga kemampuannya ini dapat berguna bagi dirinya dan lingkungan sekitar agar dapat bertahan hidup dengan baik dengan eksistensi diri yang maksimal. Oleh karena itu, urgensi stimulasi kreativitas ditanamkan sejak dini, dengan harapan yang lain anak akan mampu memanfaatkan apa yang ada pada dirinya dan lingkungan sehingga menjadi nilai lebih dan bermanfaat untuk semua. Pada anak usia dini stimulasi biasa dilakukan melalui berbagai macam permaian yang eksploratif dan konstruktif sehingga aspek pekembangan anak juga berkembang.

Edukator / orangtua pada hal ini mempunyai peran yang sangat penting dalam membimbing dan sebagai fasilitator untuk membantu dirinya sendiri dan anak usia dini belajar kreatif. Kaitannya dengan pemanfaatan permainan edukatif, educator / orangtua bisa bereran sebagai desainer permainan, baik pada aktivitas ataupun alat permainannya. Hal ini dapat dilakukan dengan membaca lingkungan sekitar / memanfaatkan yang sudah agar bernilai edukatif dan mampu mengembangkan aspek perkembangan anak, lebih-lebih mempunyai nilai estetik dan ekonomi. 
Setiap manusia pada dasarnya sudah mempunyai potensi untuk kreatif, tetapi yangsering menjadi hambatan adalah manusia itu sendiri yang merasa tidak bisa kreatif. Akan tetapi hal ini akan mampu dipudarkan jika manusia menyadari bahwa dirinya mampu untuk kreatif dan terus belajar. Kreativitas merupakan suatu proses mental seseorang yang melahirkan gagasan, proses, metode ataupun produk baru yang efektif yang bersifat imajinatif, estetis, fleksibel, integrasi, diferensiasi yang berdayaguna dalam berbagai bidang untuk memecahkan masalah. ${ }^{22}$ Dari pengertian ini terdapat suatu strategi untuk membantu agar seorang dapat belajar menjadi kreatif, misalnya seperti senang membaca buku / pemikiran tokoh / orang lain, observasi di lapangan, berdiskusi, dan senang berimajinasi, sehingga seseorang mampu mengkontruksi pikirannya dengan pengalaman yang telah dilihatnya sehingga mampu menginovasikan menjadi hal yang lebih baru dan menarik.

\section{f. Pemanfaatan Permainan Edukatif : Bermain dan Permainan untuk Anak}

Pemanfaatan permainan edukatif adalah upaya untuk menggunakan / menjadikan suatu benda atau kegiatan menjadi bernilai edukatif atau meningkatkan nilai edukatifnya. Contoh, daun-daun nangka kering yang berjatuhan dari pohon dijadikan sebuah permainan edukatif dengan cara merangkainya menjadi topi mahkota. Puzzle yang semula hanya fokus menyusun menjadi

\footnotetext{
${ }^{22}$ Yeni Rachmawati \& Euis Kurniati, Strategi Pengembangan Kreativitas Pada Anak Taman Kanak-kanak, (Jakarta : Departemen Pendidikan Nasional Direktorat Jenderal Pendidikan Tinggi Rektorat Pembinaan Pendidikan Tenaga Kependidikan dan Ketenagaan Perguruan Tinggi Jakarta : 2005), hlm. 15.
} 


\section{JURNAL AL-AFKAR \\ Vol. III, No. 1, April 2015}

bentuk yang telah ditentukan, ditingkatkan nilai edukasinya dengan cara merangkaikan dengan bermain pura-pura.

Telah dituliskan sebelumnya bahwa permainan edukatif dapat menggunakan alat (media) dan ada juga yang tidak menggunakan alat. Agar mempermudah dalam pembahasan pemanfaatan permainan edukatif maka pemanfaatan permainan edukatif diklasifikasikan menjadi tiga basis: (1) pemanfaatan permainan edukatif berbasis media, (2) pemanfaatan permainan edukatif berbasis kegiatan, (3) dan pemanfaatan permainan edukatif berbasis komputer. ${ }^{23}$

\section{g. Pemanfaatan Permainan Edukatif Berbasis Media}

Media yang dimaksudkan di sini adalah benda pokok yang dapat digunakan sebagai sarana atau alat bermain yang mengandung nilai pendidikan (edukatif) dan dapat mengembangkan kemampuan anak. Media bisa berasal dari produk jadi yang dijual di pasaran dan bisa juga berasal dari membuat sendiri.

Contoh-contoh alat atau media permainan antara lain, yaitu:

1) Alat permainan anak usia 0-1 tahun:

- Tubuhnya sendiri (melalui pijatan, senam ringan)

- Mainan sederhana dengan warna2 primer yang bisa dilihat, dipegang, dipukul-pukul, bergerak

- Balok-balok berukuran sedang dengan warna yang menarik

- Benda yang empuk, anti pecah, bersih dan aman

23 Lutfiana Safitri, "Alat Permainan Edukatif untuk Anak Usia Dini”, dalam http:// edukasi.kompasiana.com, diakses 6 Maret 2015. 


\section{Al-Quran dan Pemanfatan Permainan Edukatif ...}

Atik Wartini \& Mulammad Askar

- Benda yang kokoh yang bisa dipergunakan untuk merambat dan belajar berjalan, dan lain-lain.

2) Alat permainan anak usia 1-2 tahun

- Mainan yang bisa didorong dan ditarik untuk melatih keseimbangan

- Mainan yang bisa diduduki dan dikendarai seperti mobil2an atau sepeda roda empat yang kecil

- Kursi, tangga, lorong-lorongan, ayunan bayi

- Mainan yang bisa dibawa sambil berjalan

- Balok-balok, bola, manik-manik

- Air, pasir, kacang-kacangan

- Peralatan rumah tangga sehari-hari

- Cat, spidol, krayon, buku bergambar, dan lain-lain.

3) Alat permainan anak usia 2-3 tahun:

- Sepeda roda tiga

- Bahan dan alat tulis menulis

- Puzzle, manik-manik, balok-balok

- Mainan rumah-rumahan, boneka, alat transportasi untuk bermain peran, dan lain-lain.

4) Alat permainan anak usia 3-4 tahun:

- Boneka, binatang mainan dll untuk bermain peran

- Balok-balok konstruksi

- Alat-alat keterampilan (gunting, lem, kertas)

- Puzzle, manik-manik

- Buku cerita, dan lain-lain. 


\section{$118 \frac{\text { JURNAL AL-AFKAR }}{\text { Vol. III, No. 1, April } 2015}$}

5) Alat permainan anak usia 4-5 tahun:

- Bahan-bahan untuk menggunting, merekat, melipat

- Alat bermain peran mikro dan peran makro

- Benda-benda untuk mengenal angka dan huruf

- Alat permainan diluar seperti papan jungkat jungkit, perosotan

- Balok-balok konstruksi, dan lain-lain.

6) Alat permainan anak usia 5-6 tahun:

- Alat permainan peran makro dan mikro

- Alat-alat untuk belajar angka dan huruf

- Alat permainan di luar ruang; papan titian, papan jungkat jungkit, ayunan

- Alat-alat ketrampilan untuk menggunting, menempel, melipat.

- Balok-balok berkonstruksi

- Peralatan sehari-hari (kursi, meja, sapu, kemoceng dll).

Contoh media yang telah dipaparkan ini, pemanfaatannya akan lebih optimal ketika tiga bentuk yang dipaparkan McCall dan Kavanaugh direalisasikan, yaitu menggunakan indera dan motorik saat memainkan, membangun sesuatu, dan memasukkan unsur bermain pura-pura.

\section{h. Pemanfaatan Permainan Edukatif Berbasis Kegiatan}

Kegiatan yang dimaksudkan di sini adalah kegiatan bermain tanpa menggunakan alat permainan / benda pokok tetapi lebih 


\section{Al-Qur'an dan Pemanfatan Permainan Edukatif ...}

Atik Wartini \& Mulammad Askar

dititikberatkan pada kegiatan, misalnya permainan tradisional yang mengandung nilai pendidikan (edukatif) dan dapat mengembangkan kemampuan anak.

Contoh permainan edukatif berbasis kegiatan antara lain:

1) Bermain Petak Umpet, manfaatnya yaitu untuk mengembangkan kecerdasan visual spasial, terutama melatih kemampuan untuk melihat obyek dengan tingkat kedetailan tertentu.

2) Bermain Benteng-bentengan, yaitu permaianan yang dilakukan dua kelompok anak, masing-masing kelompok menjaga agar kelompok yang lain tidak menyentuh atau mnduduku bentengnya. Permainan ini bermanfaat dalam menumbuhkan sifat kreatif, loyal, disiplin, cerdik, dan sabar dalam diri anak.

3) Bermain Membuat Kanal, permainan kelompok ini dilakukan di parit, membuat bendungan dari lumpur. Membutuhkan kerjasama, kecerdikan, disiplin, kreatif.

4) Bermain Lempar Tangkap Bola, permainan ini melibatkan koordinasi antara mata dan tangan. Adapun manfaatnya yaitu untuk melatih keseimbangan koordinasi otak anak, melatih fokus anak, serta melatih ketepatan anak dalam mengambil keputusan.

5) Bermain Tepuk, manfaat dari tepuk tangan sendiri yaitu meningkatkan kecerdasan musikal, mengembangkan gerak motorik halus, dan jika permainan secara kelompok, maka permaianan ini juga mampu meningkatkan kecerdasan sosial emosional dan kecerdasan interpersonal. 


\section{0 \\ JURNAL AL-AFKAR \\ Vol. III, No. 1, April 2015}

6) Bermain Gobag Sodor, dilakukan oleh dua kelompok. Satu kelompok sebagai penjaga di tiap batas (garis), kelompok yang lain berusaha menerobos batas yang dijaga oleh tim penjaga. Membutuhkan kekompakan, strategi, fisik, keberanian mengambil keputusan.

8) Bermain Congklak, berjalan dengan satu kaki dalam wilayah yang telah ditentukan dengan membawa amanat sebuah benda untuk dibawa dari garis awal sampai akhir. Dan lain-lain.

Permainan-permainan di atas akan bertambah manfaatnya ketika tiga bentuk yang dicetuskan McCall dan Kavanaugh direalisasikan, yaitu menggunakan indra dan motorik saat memainkan, membangun sesuatu, dan memasukkan unsur bermain pura-pura.

\section{i. Pemanfaatan Permainan Edukatif Berbasis Komputer}

Komputer yang dimaksudkan di sini adalah kegiatan bermain dengan menjadikan komputer sebagai sumber bermain. Misalnya, pemutaran lagu, film, dan game.

Permaianan berbasis komputer akan menjadi tidak edukatif ketika orang tua atau pendidik tidak mengarahkan pemanfaatannya. Bermain Game yang dibiarkan begitu saja akan berakibat gerak anak yang linier saja, jari-jari saja yang bergerak. Tetapi dengan peran orang tua dan pendidik, komputer akan lebih bermanfaat. Misalnya sebagai sarana pemutaran film edukasi (dunia hewan, dunia binatang, kisah anak sholeh, pemutaran lagu, dll. Game dapat saja diberikan tetapi harus dalam pengawasan dari sisi waktu dan tema game. 


\section{Al-Qur'an dan Pemanfatan Permainan Edukatif ...}

Atik Wartini \& Mulammad Askar

Permainan terkadang sudah dirancang untuk dijadikan alat permainan edukatif tetapi terkadang ada mainan yang dirancang karena bisnis. Misalnya boneka-boneka puteri, boneka visual dari film kartun populer, mobil-mobilan, pesawat, kapal dan lain. Terhadap alat permainan yang demikian, maka melalui ekslporatif, konstruktif, dan bermain pura-pura, alat permainan tersebut bisa menjadi bernilai edukatif. Tetapi sebaliknya, meskipun sudah dirancang sebagai alat permainan edukatif, apabila cara bermainnya tidak mengandung eksploratif, konstruktif, dan bermain pura-pura, APE tersebut kurang optimal nilai edukatifnya.

Perlu diperhatikan juga adalah menghindari menempelkan benda-benda yang semestinya sebagai APE tetapi hanya dijadikan hiasan dinding atau hanya disimpan di lemari karena takut rusak. Tetapi sebaliknya, kekreatifan pendidik akan dapat menjadikan hiasan dinding sebagai APE.

\section{PENUTUP}

Pemanfaatan permainan edukatif adalah suatu upaya menggunakan permainan edukatif atau menjadikannya lebih bermanfaat. Pemanfaatan ini baik dilakukan pada permainan edukatif dan permainan non edukatif baik yang didesain ataupun yang sudah disediakan oleh alam sekitar dan yang menggunakan alat / tanpa alat. Educator / orangtua / desainer dalam hal ini perlu selalu belajar agar mempunyai inovasi kreativitas, karena kreativitas mempunyai urgensi untuk meningkatkan nilai edukatif dan estetika permainan. Dalam pemanfaatan permainan edukatif idelnya perlu memperhatikan hal-hal sebagai berikut, yaitu : eksploratif, konstruktif, dan bermain pura-pura. 


\section{JURNAL AL-AFKAR \\ Vol. III, No. 1, April 2015}

Sebuah permainan bisa menjadi permainan edukatif ketika pemanfaatannya dioptimalkan tetapi sebaliknya, permainan edukatif bisa menjadi tidak edukatif ketika hanya difungsikan sebagai hiasan. Peran pendidik dan orang tua sangat membantu pemanfaatan sebuah permainan.

a) Pendidik meningkatkan kreatifitasnya untuk mengoptimalkan dalam menciptakan permainan dan atau alat permianan edukatif.

b) Pendidik menggali permainan tradisonal sebagai kegiatan bermainan yang edukatif.

c) Pendidik menelaah tentang ayat-ayat Al quran atau hadis yang berkenaan dengan tema"Pemanfaatan / permaiana" agar lebih inovasi dalam memanfaatkan dan mengembangkan permainan yang bersumber dari Alquran dan hadis. 


\section{DAFTAR PUSTAKA}

Badru Zaman, "Pengembangan Alat Permainan Edukatif di Lembaga Pendidikan Anak Usia Dini (PAUD)", dalam badruzaman.staf. upi.edu, diakses 6 Maret 2015.

Bukhari, Al Jami' Al Shokih Al Bukhari, Bairut : Dar Al Kutub Al Ilmiyah, 2000.

Direkturat Jenderal PAUDNI, Petunjuk teknis penyelenggaraan PAUD-TPQ. Jakarta :Direkturat Jenderal Pendidikan Anak Usia dini Nonformal dan Informal, 2011.

Eliyawati, Cucu, Pemilihan dan Pengembangan Sumber Belajar untuk Anak Usia Dini, (Jakarta : Jakarta : Departemen Pendidikan Nasional Direktorat Jenderal Pendidikan Tinggi Rektorat Pembinaan Pendidikan Tenaga Kependidikan dan Ketenagaan Perguruan Tinggi Jakarta : 2005.

Hartati, Sofia, Perkembangan Belajar pada Anak Usia Dini, Jakarta: Direktorat Pendidikan Nasional Direktorat Jenderal Pendidikan Tinggi Direktorat Pembinaan Pendidikan Tenaga Kependidikan dan Ketenagaan Perguruan Tinggi Jakarta, 2005.

Mansur, Pendidikan Anak Usia Dini dalam Islam, cet. IV, Yogyakarta: Pustaka Pelajar, 2011.

Nuraini, Indah, Kamus Bahasa Indonesia, Bogor : CV. Duta Grafika, 2010.

Rachmawati,Yeni \& Euis Kurniati, Strategi Pengembangan Kreativitas Pada Anak Taman Kanak-kanak, Jakarta : Departemen Pendidikan Nasional Direktorat Jenderal Pendidikan Tinggi Rektorat Pembinaan Pendidikan Tenaga Kependidikan dan Ketenagaan Perguruan Tinggi Jakarta : 2005. 


\section{JURNAL AL-AFKAR \\ Vol. III, No. 1, April 2015}

Rahmat,"Memanfaatkan Permainan Bagi Pendidikan

Emosional”, jurnal : Ilmu Pendidikan Islam : Kajian tentang Konsep, problem dan prospek pendidikan Islam, No. 2, Tahun 2003.

Rolina, Nelva, Alat Permainan Edukatif PAUD, Yogyakarta : Ombak, 2012.

Rumanda, Yohana dan Hikmah, Pembelajaran Anak Usia Dini yang Menyenangkan Melalui Bermain, Kemendiknas, Dirjen PAUDNI, Direktorat PPTK PAUDN, 2011.

Safitri, Lutfiana, "Alat Permainan Edukatif untuk Anak Usia Dini", dalam http://edukasi.kompasiana.com, diakses 6 Maret 2015.

Shihab, M. Qurais. Tafsir Al Misbah Pesan, Kesan dan Keserasian Al Qur'an, Jakarta : Lentera Hati, 2002.

Trisnawati, "Efektivitas Permainan Lego dalam Meningkatkan Kreatifitas Anak Usia Prasekolah”, dalam digilib.uinsby.ac.id, diakses 6 Maret 2015. 